\title{
SUITABILITY OF 'JONAGOLD’ APPLE CLONES FOR COMMERCIAL GROWING IN LITHUANIA
}

\author{
Darius Kviklys, Nomeda Kviklienè, and Nobertas Uselis \\ Institute of Horticulture, Lithuanian Research Centre for Agriculture and Forestry LT-54333, Babtai, Kaunas distr. \\ E. mail: d.kviklys@Isdi.lt
}

Communicated by Edite Kaufmane

\begin{abstract}
Seven apple clones of cv. 'Jonagold': 'Red Jonaprince', 'Jonagold Boerekamp', 'Jonagored Supra', 'Jonaveld', 'Jonagold DeCoster', 'Jonagold Novajo' and 'Jonabel' were tested at the Institute of Horticulture in Babtai in 2003-2011. Significant differences among cv. 'Jonagold' clones were recorded in yield, fruit quality parameters and winter hardiness. The highest total yield was recorded for cvs. 'Jonagold Boerekamp' and 'Red Jonaprince', the lowest for cv. 'Jonagold Novajo'. Average fruit weight of cv. 'Jonagold Novajo' was significantly lower. 'Red Jonaprince' fruits had the best colouration. 'Jonagored Supra' fruits had the best appearance according to the test panel. During winter 2009-2010, 30\% of 'Red Jonaprince' trees suffered frost damage. No losses were recorded for 'Jonagored Supra'. During the experiment tree losses due to frost and disease damages were $25-60 \%$ and depended on the clone.
\end{abstract}

Key words: Malus sp., yield, fruit quality, winter hardiness.

\section{INTRODUCTION}

Numerous trials recently established throughout the world demonstrate the importance of cv. 'Jonagold' (Cline et al., 2010; Von Benewitz et al., 2011; Dreesen et al., 2012). Cv. 'Jonagold' was created in 1968 at Cornell University USA and numerous clones are known (Kemp and Van Dieren, 1996; Brown, 1997). Cv. 'Jonagold' is widely planted in commercial orchards in Europe. Until recent years, 'Jonagold' is one of the main grown varieties in the Netherlands, Belgium, Germany and Poland (Jadczuk, 2000). The main clones grown and currently planted in these countries are 'Jonagored Supra', 'Jonagold DeCoster' and 'Red Jonaprince' (Jager and Kemp, 2000).

In earlier performed rootstock trials at the Institute of Horticulture (Lithuania) with standard cv. 'Jonagold', fruits lacked colour, especially on more vigorous rootstocks. Other fruit quality parameters and taste were not sufficient every year (Kviklys and Kvikliené, 2002). Therefore, clones with better colouration can help to overcome some shortcomings of the standard cultivar.

The aim of the trial was to evaluate suitability of cv. 'Jonagold' clones for growing under the Lithuanian climatic conditions.

\section{MATERIAL AND METHODS}

Seven clones of cv. 'Jonagold': 'Red Jonaprince', 'Jonagold Boerekamp', 'Jonagored Supra', 'Jonaveld', 'Jonagold De-
Coster', 'Jonagold Novajo' and 'Jonabel' grafted on M.9 rootstock were tested at the Institute of Horticulture, Lithuanian Research Centre for Agriculture and Forestry in Babtai (Central Lithuania 55 $60^{\prime} \mathrm{N}, 23^{\circ} 48^{\prime} \mathrm{E}$ ) in 2003-2011. The orchard was planted in spring 2003. Planting material was propagated in the Netherlands as knip-trees and obtained from Vermeerderingstuinen Nederland (Propagation Gardens of the Netherlands). Planting distances were $3 \times 1 \mathrm{~m}$. The orchard was established without irrigation. Trees were trained as slender spindle. Weed-free strips (1.5 m wide) were maintained along the tree rows, with herbicide applications. The grassed alleyways were mowed. Pest and disease management was carried out according to the rules of integrated plant protection.

Fruit yield from each tree was recorded and the average yield per tree of a replicate (in $\mathrm{kg}$ ) was calculated. Mean fruit weight $(\mathrm{g})$ was determined from every tree and the average for each replicate was derived.

Investigations of internal and external fruit quality parameters were performed at harvest time. Fruit blush (surface red colour) was estimated by visual evaluation and expressed as percentage of skin covered with red blush. Firmness was measured with a penetrometer (FT-327) with 11-mm diameter probe and expressed in $\mathrm{kg} \cdot \mathrm{cm}^{-2}$. Soluble solid content (SSC) was measured with a refractometer and expressed as percentage of fresh weight. The starch index was determined using a $0.1 \mathrm{~N}$ iodine and potassium iodine solution (scale 1-10). Maturity index was calculated as F/RS, where 
F - firmness, $\mathrm{R}$ - concentration of soluble solids, $\mathrm{S}$ - starch conversion.

Fruit taste and appearance was evaluated by the Pomological Commission of the Institute of Horticulture using a 5point scale.

Dead trees were counted and the reason of mortality (frost damages or bark diseases (cancer) damages) was determined.

Meteorological conditions during the trial were favourable for apple growing, with the exception of two severe successive winters in 2009-2010 and 2010-2011. Meteorological station data (Pessl Instruments) showed that temperatures dropped down to minus $27{ }^{\circ} \mathrm{C}-30.4{ }^{\circ} \mathrm{C}$ during five successive days at the end of January 2010, and down to minus $31.5^{\circ} \mathrm{C}$ in the middle of February 2011.

The trial was arranged in randomised block design, with four replicates and five trees per plot. Replicates were randomised. Significant differences in main traits were tested by analysis of variance. Significance of differences between treatment means was evaluated using LSD test at $P<0.05$.

\section{RESULTS}

First tree losses occurred due to bark diseases and tree cancer in the young orchard. There were no significant differences between 'Jonagold' clones; number of dead trees was 5-15\% during 2003-2009 (Table 1).

Cvs. 'RedJonaprince' and 'Jonabel' were the most susceptible to frost during winter 2009-2010, while there were no killed trees of cv. 'Jonagored Supra'. Tree mortality was recorded for all tested 'Jonagold' clones after the winter 2010-2011. Taking into account only frost damage, cv. 'Red Jonaprince' was the most susceptible and $45 \%$ of trees were frozen. Cvs. 'Jonagored Supra' and 'Jonagold Novajo' appear to be the most winter hardy clones.

Total tree loss during nine years of the testing was significantly highest for cv. 'RedJonaprince'. High tree mortality rate due to bark diseases and frost was recorded also for $\mathrm{cv}$. 'Jonaveld' .
Table 1

MORTALITY OF CV. 'JONAGOLD' CLONES TREES DURING 2003-2011, \%

\begin{tabular}{l|c|c|c|c}
\hline \multicolumn{1}{c|}{ Clone } & $\begin{array}{c}2003- \\
2009\end{array}$ & $\begin{array}{c}2009- \\
2010\end{array}$ & $\begin{array}{c}2010- \\
2011\end{array}$ & $\begin{array}{c}\text { Total } \\
(2003- \\
2011)\end{array}$ \\
\hline Red Jonaprince & 15 & 30 & 15 & 60 \\
Jonagold Boerekamp & 10 & 5 & 15 & 30 \\
Jonagored Supra & 15 & 0 & 10 & 25 \\
Jonaveld & 15 & 10 & 15 & 40 \\
Jonagold DeCoster & 15 & 5 & 15 & 35 \\
Jonagold Novajo & 10 & 10 & 5 & 25 \\
Jonabel & 5 & 20 & 10 & 35 \\
LSD 05 & 10.2 & 7.6 & 10.3 & 12.3 \\
& & & &
\end{tabular}

Table 2

YIELD OF CV. 'JONAGOLD' CLONES IN 2003-2010

\begin{tabular}{l|c|c|c}
\hline \multicolumn{1}{c|}{ Clone } & $\begin{array}{c}\text { Total yield, } \\
\mathrm{kg} / \text { tree } \\
2003-2010\end{array}$ & $\begin{array}{c}\text { Annual average } \\
\text { yield, t/ha } \\
2003-2006\end{array}$ & $\begin{array}{c}\text { Annual average } \\
\text { yield, t/ha } \\
2007-2010\end{array}$ \\
\hline Red Jonaprince & 67.6 & 18.5 & 42.5 \\
Jonagold Boerekamp & 68.7 & 20.3 & 42.0 \\
Jonagored Supra & 63.3 & 18.1 & 39.2 \\
Jonaveld & 57.6 & 17.1 & 35.2 \\
Jonagold DeCoster & 61.6 & 17.0 & 38.6 \\
Jonagold Novajo & 57.3 & 15.8 & 36.0 \\
Jonabel & 57.1 & 16.4 & 35.3 \\
LSD 05 & 4.5 & 3.1 & 4.3
\end{tabular}

Significant yield differences were found among some of tested clones (Table 2). The highest total yield per tree was harvested from cv. 'Jonagold Boerekamp'. Only cv. 'Red Jonaprince' did not differ significantly from clone in yield. Cv. 'Jonagored Supra' had high yield alos. The mentioned three cultivars had the highest average yield both in young and full bearing orchards. Cvs. 'Jonaveld' and 'Jonabel' were the least productive at this stage. Average yield of most tested clones in the young orchard was less than $20 \mathrm{t}$ $\mathrm{ha}^{-1}$, but the average yield in full bearing orchard was more than double.

There were no significant differences in fruit weight among most clones (Table 3). However, average fruit weight of cv.

Table 3

FRUIT QUALITY CHARACTERISTICS OF CV. 'JONAGOLD’ CLONES, MEAN 2008-2010

\begin{tabular}{|c|c|c|c|c|c|c|c|c|}
\hline \multirow[t]{2}{*}{ Clone } & \multirow{2}{*}{$\begin{array}{l}\text { Average fruit } \\
\text { weight, g }\end{array}$} & \multirow[t]{2}{*}{ Blush, \% } & \multicolumn{3}{|c|}{ Fruit size distribution according diameter, $\%$} & \multicolumn{3}{|c|}{ Panel test results, points } \\
\hline & & & $60-65 \mathrm{~mm}$ & $70-80 \mathrm{~mm}$ & $85-95 \mathrm{~mm}$ & $\begin{array}{c}\text { fruit } \\
\text { appearance }\end{array}$ & taste & $\begin{array}{c}\text { overall } \\
\text { score }\end{array}$ \\
\hline RedJonaprince & 212 & 99 & 1 & 28 & 71 & 4.49 & 4.28 & 4.35 \\
\hline Jonagold Boerekamp & 223 & 86 & 0 & 32 & 68 & 4.42 & 4.43 & 4.44 \\
\hline Jonagored Supra & 226 & 85 & 0 & 32 & 68 & 4.58 & 4.24 & 4.38 \\
\hline Jonaveld & 224 & 80 & 0 & 27 & 73 & 4.42 & 4.34 & 4.36 \\
\hline Jonagold DeCoster & 221 & 77 & 0 & 28 & 72 & 4.47 & 4.42 & 4.40 \\
\hline Jonagold Novajo & 183 & 73 & 0 & 46 & 54 & 4.36 & 4.30 & 4.31 \\
\hline Jonabel & 219 & 70 & 0 & 35 & 65 & 4.35 & 4.41 & 4.35 \\
\hline $\mathrm{LSD}_{05}$ & 20.3 & 11.1 & & 12.2 & 13.7 & 0.12 & 0.20 & 0.15 \\
\hline
\end{tabular}


'Jonagold Novajo' was significantly lower and did not reach $200 \mathrm{~g}$. The same differences were observed when fruits were sorted in classes by their diameter. The largest part of graded fruits was in the 85-95 mm class, while significantly more cv. 'Jonagold Novajo' fruits were in the $70-80 \mathrm{~mm}$ class and significantly less in the $85-95 \mathrm{~mm}$ class, compared to other tested clones.

Fruits of cv. 'Red Jonaprince' were totally covered by dark red blush. Fruits of all other tested clones had rich colouration also, but significantly less than cv. 'Red Jonaprince'.

According to the panel test results, fruits of cv. 'Jonagored Supra' obtained the highest score for appearance. Cvs. 'Red Jonaprince' and 'Jonagold DeCoster' fruits had lower scores, but not significantly. No significant differences were recorded among 'Jonagold' clones in fruit taste and overall evaluation.

Fruit maturity characteristics such as flesh firmness, starch index, soluble solid content and maturity index on average did not significantly differ among clones (Table 4). More distinct differences appeared only in separate years. Higher fruit flesh firmness was recorded for cvs. 'Jonagold Boerekamp' and 'Jonagored Supra', and less soluble solid content for cv. 'Red Jonaprince'. A tendencies for earlier ripening was observed for cv. 'Jonabel'.

\section{DISCUSSION}

The vegetation period is shorter, and sum of active temperatures is lower in Northern Europe than in other European countries. Winters could also be a limiting factor for apple cultivar performance. Highly productive winter apple cultivars with large and attractive fruits are urgently needed for the Lithuanian market. The tested 'Jonagold' clones were very productive. Average yield around $40 \mathrm{t} / \mathrm{ha}$ is not common in Lithuanian orchards. Very few commercial apple cultivars like 'Ligol' and 'Shampion' reach such a yield (Uselis, 2006; Uselis and Kviklys, 2007). Fruit quality characteristics like weight and colouration were excellent for all tested clones, although average fruit weight was smaller than in countries with more favourable climate conditions (Czynczyk et al., Vercamen and Gomand, 2011).

Most of the 'Jonagold' clones were selected as colour mutations. Nevertheless, differences in yield and other productivity parameters were observed in our trials, which is not mentioned in others.

'Jonagold' clones did not differ in fruit internal quality characteristics. Ripening and maturation processes were similar for all tested clones too. No significant differences in ripening were found also between clones in other countries, especially when trees had the same crop load and the same virus status. (Hampson and Kemp, 2003).

Fruits of the tested clones accumulated moderate amounts of soluble solids. Lower SSC was observed for cv. 'Red Jonaprince'. Usually, content of soluble solids of late-ripen-
Table 4

FRUIT MATURITY CHARACTERISTICS OF CV. 'JONAGOLD' CLONES, MEAN 2008-2010

\begin{tabular}{lcc|c|c}
\hline \multicolumn{1}{c|}{ Clone } & $\begin{array}{c}\text { Firmness, } \\
\mathrm{kg} / \mathrm{cm}^{2}\end{array}$ & $\begin{array}{c}\text { Starch } \\
\text { index, points }\end{array}$ & SSC, \% & $\begin{array}{c}\text { Maturity } \\
\text { index, points }\end{array}$ \\
\hline RedJonaprince & 8.3 & 8.5 & 12.8 & 0.076 \\
Jonagold Boerekamp & 8.7 & 8.3 & 13.7 & 0.077 \\
Jonagored Supra & 8.7 & 8.4 & 13.5 & 0.077 \\
Jonaveld & 8.4 & 8.1 & 13.4 & 0.077 \\
Jonagold DeCoster & 8.3 & 8.1 & 13.3 & 0.077 \\
Jonagold Novajo & 8.5 & 8.3 & 13.2 & 0.078 \\
Jonabel & 8.5 & 8.2 & 13.9 & 0.075 \\
LSD 05 & 0.52 & 0.47 & 1.13 & 0.004
\end{tabular}

ing cultivars is correlated with temperatures and vegetation period. In neighbouring Poland, SSC in 'Jonagold' fruits is higher (Tomala et al., 2008).

The main feature of the newly introduced cultivars in Lithuania and other north-eastern European countries should be winter hardiness. Surprisingly, 'Jonagold' clones differ in their resistance to cold damages. This could not be explained by higher or lower yield, or fruit harvesting time, which are associated with tree acclimatisation for wintering. In spite of equal conditions for all tested clones, apple trees of cvs. 'Jonagored Supra' and 'Jonagold Novajo' suffered significantly less frost damage during two successive severe winters.

Taking into account productivity parameters, fruit internal and external qualities, and especially winter hardiness, only cv 'Jonagored Supra' could be grown in a commercial scale under Lithuanian climate conditions.

\section{ACKNOWLEDGEMENTS}

This work was carried out within the framework of the long-term research programme "Horticulture: agro-biological basics and technologies" implemented by Lithuanian Research Centre for Agriculture and Forestry.

\section{REFERENCES}

Brown, S. (1997). Varieties of Commercial Interest: 'Jonagold'. NY Food Life Sci. Bull., 150. Retrieved 15 August 2012, from http://fls.cals.cornell.edu/OCRPDF/150.pdf.

Cline, J. A., Norton, D., Embree, C. G., Prive, J. P. (2010). Performance of Jonagold, McIntosh and Novaspy on three new semi-dwarf apple rootstocks in eastern Canada. Can. J. Plant Sci., 90, 877-883.

Czynczyk, A., Bielicki, P., Bartosiewicz, B. (2006). Growth and yielding of 'Jonagold' and 'Ligol' apple trees on M.9 and P 22 subclones and some other Polish rootstocks. Sodininkystè ir daržininkystè, 25 (3), 173-180.

Dreesen, R., Keulemans, J., Prinsen, E., Denruyter, L., Gomand, A., Vercammen, J. (2012). A multidisciplinary approach to study the influence of pollination and plant growth regulators on fruit set and early fruit development in apple. Acta Hort., 932, 91-99.

Hampson, C. R., Kemp, H. (2003). Characteristics of important commercial apple cultivars. In: Ferree, D. C., Warrington, I. J. (eds.). Apples. Botany, Production and Uses (660 pp.). CABI Publishing, UK. 
Jadczuk, E. (2000). Growth and bearing of 'Jonagold' apple trees on eight rootstocks. Acta Hort., 517, 175-182

Jager, A., Kemp, H. (2000). Red Jonaprince: Betere maat en meer blos. De Fruitteelt, 90 (16), 18-19.

Kemp, H., Van Dieren, M. C. A. (1996). Clone Trials in Regional Experimental Gardens. Annual Report. Fruit Research Station, Wilhelminadorp, The Netherlands, pp. 50-51.

Kviklys, D., Kviklienė, N. (2002). Effect of rootstock on apple quality and storability. Folia Horticult., 14 (1), 227-233.

Tomala, K., Andziak, J., Jeziorek, K., Dziuban, R. (2008). Influence of rootstock on the quality of 'Jonagold' apples at harvest and after storage. $J$. Fruit Ornamental Plant Res., 16, 31-38.
Uselis, N., Kviklys, D. (2007). Evaluation of apple cultivars on M.9 rootstock in intensive planting system. Sodininkystè ir Daržininkystè, 26 (3), 115-120.

Uselis, N. (2006). Influence of rootstocks and planting schemes of apple tree cv. 'Ligol' on productivity and fruit quality. Sodininkystè ir Daržininkystè, 25 (3), 151-157.

Vercammen, J., Gomand, A. (2011). Improvement of the fruit set of 'Jonagold' apple. Acta Hort., 903, 789-794.

Vercammen, J., Van Daele, G., Gomand, A. (2007). Can fruit size and colouring of 'Jonagold' be improved by an interstock? Acta Hort. (ISHS), 732, $165-170$

Von Bennewitz, E., Cooper, T., Benavides, C., Losak T., Hlusek, J. (2011). Response of 'Jonagold' apple trees to $\mathrm{Ca}, \mathrm{K}$ and $\mathrm{Mg}$ fertilization in an andisol in southern Chile. J. Soil Sci. Plant Nutr., 11 (3), 71-81.

Received 16 November 2012

\section{ŠK়IRNES 'JONAGOLD’ KLONU PIEMĒROTĪBA KOMERCIĀLAI AUDZĒŠANAI LIETUVĀ}

Septiņi šķirnes ‘Jonagold’ kloni: ‘Red Jonaprince', ‘Jonagold Boerekamp’, ‘Jonagored Supra', ‘Jonaveld', 'Jonagold DeCoster', ‘Jonagold Novajo' un 'Jonabel' tika pārbaudīti Lietuvas augḷkopības institūtā Babtai 2003.-2011. gadā. Novērotas būtiskas škirnes 'Jonagold' klonu atšķirības ražībā, aug̣̣u kvalitātes parametros un ziemcietībā. Lielākā kopējā raža novērota kloniem 'Jonagold Boerekamp' un 'Red Jonaprince', zemākā — 'Jonagold Novajo'. Klonam 'Jonagold Novajo' vidējā aug̣̣u masa bija būtiski mazāka. 'Red Jonaprince' augḷiem bija vislabākais krāsojums. 'Jonagored Supra' aug̣̣i bija visizskatīgākie pēc degustācijas grupas vērtējuma. 2009.-2010. gada ziemā 30\% 'Red Jonaprince' koku nosala, bet 'Jonagored Supra' nebija bojā gājušu koku. Pētījumu periodā koku izkritumi sala un slimību bojājumu dēḷ bija 25-60\% atkarībā no klona. 